\title{
Mapping Strategy Development Of Traveler Destinations In Empowerment Local Community East Coast In South Sulawesi
}

\author{
Andi Cudai Nur ${ }^{1}$, Risma Niswati ${ }^{2}$, Slamet Riadi Cante ${ }^{3}$, Delly Mustafa ${ }^{4}$, Haedar Akib ${ }^{5}$
}

${ }^{1}$ Senior Lecturer Universitas Negeri Makassar

${ }^{2}$ Lecturer Universitas Negeri Makassar

${ }^{3}$ Senior Lecturer Universitas Tadulako

${ }^{4}$ Senior Lecturer Universitas Pejuang Republik Indonesia

${ }^{5}$ Senior Lecturer Universitas Negeri Makassar

Makassar, Indonesia

Corresponding Author e-mail: cudainur@unm.ac.id

\begin{abstract}
Research carried out to identify, analyze, and orientation of the mapping strategy to support the development of tourism destinations empowering local communities an area-based tourism as its leading sector. The approach used is qualitative and quantitative mix techniques. The results showed that developments rating in Sinjai can be seen from: 1) traveler, 2) traveler destination, 3) traveler activities, 4) of accommodation used, 5) traveler trips, 6) average expenditure, 7) characteristics of the traveler market. From the description on the results of the study has increased every year. This is because sights increasingly supported by adequate infrastructure. The mapping showed an increase and expansion of the traveler area each year. Increased traveler destinations and the availability of adequate infrastructure provide the opportunity for local communities to participate in the tourism industry that contribute to the empowerment of local communities. The government's efforts in promoting the expansion of development opportunities in various sectors of the tourism sector strongly support the improvement of the economy and social life of the local community level.
\end{abstract}

\section{ARTICLE HISTORY}

Submitted:17.11.2021

Revised:20.12.2021

Accepted:04.01.2022

Online first:05.01.2022

\section{KEYWORDS}

Empowerment, Local communities, The tourism potential, Development 


\section{Introduction}

Indonesia as a country that consists of thousands of islands (archipelago), has diverse natural beauty and the population is comprised of hundreds of tribes (air-Unity), it is a tremendous tourist potential to be developed. The existence of nature, social and great cultural wealth is an opportunity for the development of tourism in Indonesia. Given the major attraction of tourists visiting Indonesia is because of its natural beauty and wealth of art and culture, as well as the hospitality of its inhabitants are available naturally.

Achievement of Indonesian tourism development in the period 2010-2014 among others accounted for 4 percent of the Gross Domestic Product (GDP) National (4th ranking national foreign exchange earner after oil and gas, coal, and oil palm). Similarly, contribute to the absorption of 10.13 million workers and generate national foreign exchange amounted to 10 billion USD (Destination Development Strategic Plan and Tourism Industry in 2015-2019).

Sinjai as one of the districts in South Sulawesi province has the potential areas of sea, land and mountains with an area of $223 \mathrm{~km} 2$ and has a population of 238099 inhabitants. This area has a tourism destination or saving potential is quite promising. It is expected that tourism can develop optimally by government support, private sector and local communities, the tourism destination which was well managed is one of the key factors in job creation, business development, and improvement of infrastructure, facilities and supporting infrastructure. Sinjai has many interesting tourist destinations to visit. One of them is Pulau Sembilan which consists of a cluster of nine islands with sea water is very clear. Of the nine islands, the island Larea-Rea is one of the excellent of Pulau Sembilan. Outspread white sand beaches and crystal clear sea water make it look exotic.

In addition to maritime charm Pulau Sembilan, Sinjai has the charm of mangrove forest located in the village Tongke-Tongke, Eastern Sinjai district. Mangrove forest is a central area of mangrove restoration and learning with an area of 173.5 hectares. Expanse of mangrove forests can be enjoyed by walking through a solid bridge of ironwood establish long hallways that are connected to each other. Visitors can also rent a speed boat to get around enjoying the scenery of mangrove forest. There was also the peak Batupake Gojeng see downtown where the Sinjai District with beautiful natural scenery so motivated by the green mangrove forest 
Edutourism Journal of Tourism Research $\quad$ p-ISSN: 2686-4746 e-ISSN: 2721-1371

development Sinjai (mangrove) in the village of Tongke-Tongke excl. East Sinjai and rows of nine islands (the cluster of small islands) are still part of the district of Sinjai.

\section{Literature Review}

\section{a. The importance of strategy management}

Strategic management is a form of modern management thinking paradigm. The position of strategic management in public administration is not as a theory but rather serves as a theoretical instrument in implementing various approaches in public administration, especially in New Public Management (NPM). Because strategic management enables organizations to detect a variety of very dynamic environmental changes. Hunger and Wheelen (Achmad, 2010: 79) fully explain the process of the birth of strategic management through 4 (four) phases, namely:

1. Basic financial : seeking better operational control through the meeting of budgets.

2. Forecastbased planning : seeking more effective planning for growth by trying to pre dict the future beyond the next year.

3. Externally oriented planning ( strategic planning ): seeking Increased responsiveness to markets and competition by trying to think Strategically.

4. Strategic Management : seeking to manage all resources to develop competitive adve ntage and to help create a successful future.

Hunger and Whelen (Achmad, 2010: 81) strategic management is everything that is decided and implemented by managers as part of long-term performance. Meanwhile, Nawawi (2012: 148) defines strategic management as a process or series of decision-making activities that are fundamental and comprehensive, accompanied by determining how to carry it out, which is made by top management and implemented by all levels in an organization to achieve its goals.

Several authors have approached the concept of strategic management in a very pragmatic manner and defined it as a process in which the organization organizes itself for the achievement of organizational goals through: 1) proportional strategic analysis; 2) The formulation of a strategy that is used as excellence; 3) Accurate strategy implementation; and 
4) Evaluating the maximum of its performance (Houthoofd in Heene 2010: 76). While other authors tend to be at the rear, which describes the management and strategic as as a process which in principle guarantee the implementation of the development and implementation of a strategy that also gave direction to the operational activities of the organization ( Schendel in Heene 2010: 76). Besides that, Viljoen (in Heene 2010: 76) expresses a very detailed interpretation by assuming that strategic management is a process of identifying, selecting, and implementing activities that can improve the long-term performance of the organization, through determining direction accompanied by continuing commitments or the adjustment between internal skills and the means of the organization as well as the evolutive changing environment in which the organization operates. Later expected organisasi should try to bring a holistic approach to the management of its strategic, with the understanding that:

- The attention of the entire organization is focused on unified objectives, phenomena and problems that are not addressed by technical divisions, and the existence of unequal arrangements within the organization.

- Internal management programs and processes are integrated with the achievement of the expected results from the organization.

- Daily operational and tactical decisions are simultaneous within flexible boundaries for the achievement of the long-term strategic goals of the organization (Poister in Heene 2010: 76).

Management strategic represents the unity of management processes in an organization that is repeated to create value as well as the ability to deliver and expand its distribution to stakeholders or pihal other interested parties. This means that strategic management becomes a unit of the entire integrated process, which can be divided into 6 strata (Heene, 2002: 9), namely:

1. Not too systematic, only relying on intuitive analysis in assessing the organizational environment. Especially specifically when you want to get a picture of what kind of social value will be created in order to produce achievement (output) and the formation of community affective responses ( outcomes).

2. Various options were considered and planned for realizing this value creation. 
3. Not too systematic, only relying on intuitive analysis and evaluating various options for creating social value.

4. Select one or more of the various possibilities for social value creation

5. Further development of various possibilities to create societal value, then the most appropriate is selected from the available alternatives .

6. Seeking and developing various possibilities to obtain the means needed to achieve social value creation

In summary, we can formulate the six strata of the strategic management process into five mainstay tasks that every manager should master in order to guide the strategic steps of his organization (Thompson in Heene 2010: 10). The five mainstay tasks are as follows: a) Developing the existing vision and mission so that it is clear about the reasons for the formation of the organization and what it aims to achieve; b) Interpret and describe its strategic vision and mission into concrete goals and targeted goals as desired by the organization; c) Develop various strategies to achieve predetermined goals; d) Implementing strategic choices effectively and efficiently; d) Evaluate the success of the strategy, re-synergize mistakes found between existing task forces and participate in directing them if deemed necessary.

In simple terms, the elements of strategic management can be described as follows:

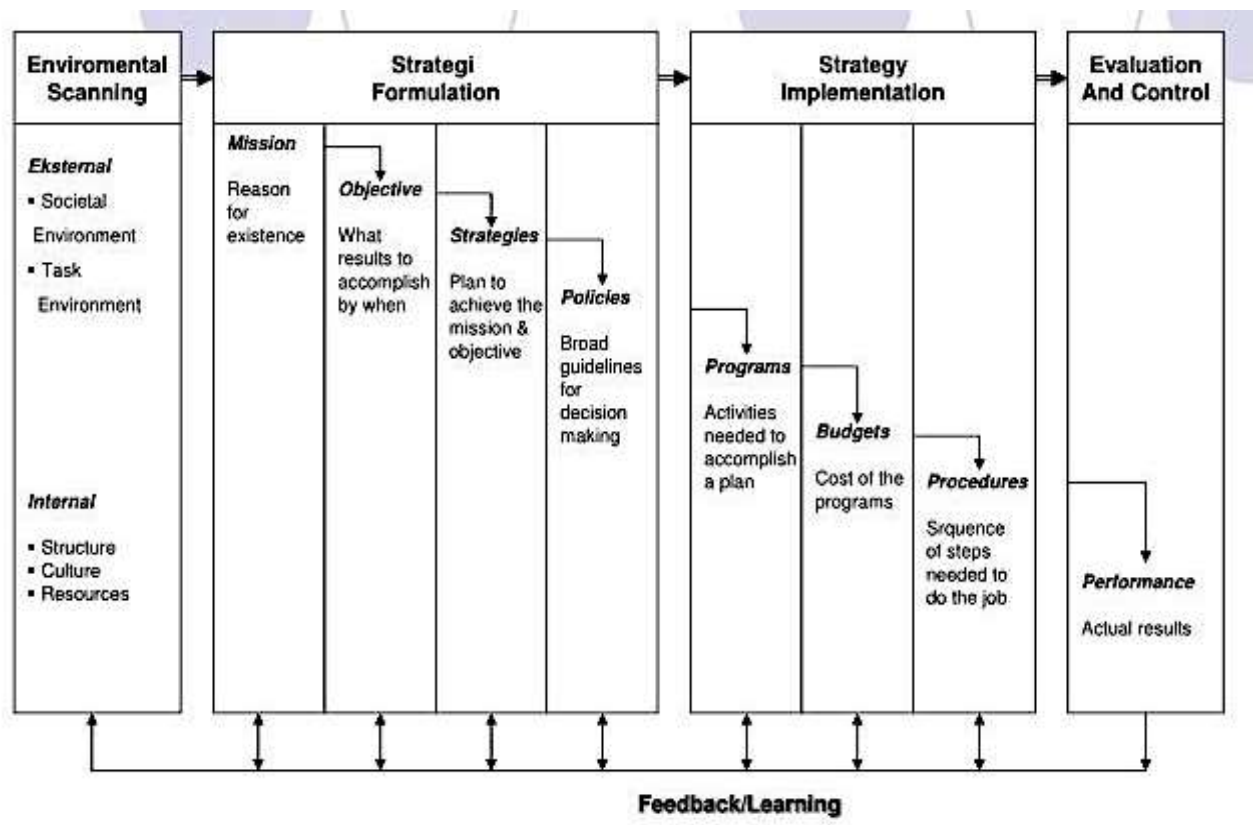

Hunger and Wheelen's Strategic Management Model

Source: Achmad (2010: 86). Recent Theories of Public Administration 


\section{b. Traveler interest in tourism}

Etymologically, tourism comes from Sanskrit, namely "Pari" means "a lot, many times, spinning" and the word "tourism" means "traveling". Based on the meaning of this word, tourism is defined as a trip carried out many times or circling from one place to another with a particular goal and purpose (Simanjuntak, Tanjung, \& Nasution, 2017: 1). In the Law of the Republic of Indonesia No. 10 of 2009 concerning tourism, it was explained that tourism was a variety of tourism activities and supported by various facilities and services provided by the community, businessmen, government and local government.

According to Yoeti (2003) the requirements for travel are referred to as tourism trips if: 1) travel made from one place to another, outside where the person usually lives; 2) The purpose of the trip is solely for fun and does not make a living in the place or country that he visits; 3) solely as a consumer in a place visited.

The concept and definition of tourism, tourists and their classification needs to be determined because of their dynamic nature. In tourism, according to Leiper (Ismayanti, 2011: 1). Basically, activity activities consist of several main components that need to be understood, namely: 1) Tourists, are actors in tourism activities; 2) Geography elements, travel movements take place in three geographical regions, namely: a) originally travelers; b) transit area; c) tourist destination; 3) The tourism industry, which is the third element in the tourism system that provides tourism services, attractions and facilities.

Attractions are actually other words for tourism objects, but in accordance with Indonesian Government Regulation 2009, attractions are no longer relevant to mention tourist destinations (Suryadana \& Octavia, 2015: 5). Hanief \& Pramana (2018: 29), concluded that tourism goals are areas that cover certain geographical areas that have components such as tourist attractions, tourism service facilities, accessibility, and people who ignore visits from tourists. Tourism development is very important to find out the interest of tourists in tourism destinations that can be adjusted, so the development of the tourism industry can provide broader benefits and in accordance with what has been formulated and defined its success in achieving the desired target, both from economic, social perspectives, Culture and Environment (Yoeti, 2016: 47). 


\section{Methodology}

The research method used is a mixed or combination method, where researchers conduct collaborative research (such as social collaboration, behavioristic collaboration, and humanistic collaboration). In accordance with the needs of this study begins with quantitative methods first, then qualitative. What underlies this research model is that the quantitative data obtained in the first stage can provide a general description (generalization) of the research problem, for further analysis it is necessary to have qualitative data to explain the general picture (Creswell, 2011:77). Putra (2017:7), suggests several advantages possessed by mixed quantitative and qualitative research, namely: 1) allows asking complex research questions; 2) can obtain richer and comprehensive data; 3) the results of the study will have high credibility because of the triangulation.

The central premise on this method is based is to use a combination of quantitative and qualitative approaches to find better research results than if only using one approach (Ujang Murana, download July 2016, 22:21 23). After all research data has been collected, an analysis of the development of tourism destinations in Sinjai Regency using TOWS analysis techniques, namely analysis to find challenges, opportunities, weaknesses, strengths to the design of integrated tourism destination development strategies in Sinjai Regency.

\section{Results and Discussion}

Growth and development of an area is determined by the number of inhabitants. Based on 2018 statistics, the population of Sinjai in 2017 amounted to 241208 inhabitants, with a sex ratio of a population of 94 percent, which is composed of 116766 inhabitants of the male and female population of 124442 inhabitants. The spread of the population of Sinjai regency was the largest domicile in the district of North Sinjai ie 47091 inhabitants, while the smallest population of the island is in the district of Nine is numbered 7594 people.

During the period 2010-2017, the rate of population growth Sinjai regency was accelerated by 5.06 percent. While the population density per $\mathrm{km} 2$, where as many as 294 people. Areas with the greatest population density is District North Sinjai which reached 1592 inhabitants $/ \mathrm{km} 2$, while the lowest population density is located in the District of Fur Poddo which only reached 161 people/km2. 


\section{a. Mapping Tourism Potential in Sinjai}

Sinjai tourist attraction consists of coastal tourist attraction, caves, sea, islands, agro, cultural history of the community, as well as events (events tourism). Meanwhile, the potential tourist attraction Sinjai can be seen from the aspect of history, socio-cultural aspects of society and other sectors that may be affected.

- Potential Nature: Potential and competence of natural resources is one of the major tourist attraction in Sinjai which can be interesting for tourists to visit this area.

- Potential Man-Made Travel (Manmade) and Special Interest: Sinjai have the potential man-made tourist attraction that is enough to attract tourists at the time of the visit, in addition to potential natural attractions, history and culture. Artificial tourism potential is any appeal made (engineered) or built by humans is planned as a means for the traveler in conducting tourism activities. In addition to man-made tourist potential (man-made), the potential for special interest tours are also a means or activities required by tourists during a visit to Sinjai.

- Potential special interest referred to in this case is the activity, in addition to special interests and other coastal tourist activities and rock climbing that has been operationally attached to the natural attractions that have been put forward on the potential table above. Man-made tourist attraction and special interests Sinjai are presented in the following table:

\section{Table}

Potential Man-Made Travel and Special Interest Sinjai 2020

\begin{tabular}{|c|c|c|c|}
\hline No. & Name Destinations & Attractiveness & $\begin{array}{l}\text { Location(sub- } \\
\text { district) }\end{array}$ \\
\hline 1 & Agro Tourism Industry Susin & $\begin{array}{l}\text { Cattle and processing the milk } \\
\text { and ice cream }\end{array}$ & West Sinjai \\
\hline 2 & $\begin{array}{l}\text { Green Garden } \\
\text { Pasanggarahan Manipi }\end{array}$ & $\begin{array}{l}\text { 1. Pine forests } \\
\text { 2. Sculpture }\end{array}$ & West Sinjai \\
\hline 3 & $\begin{array}{l}\text { Agro Tourism Vegetable } \\
\text { Gardens }\end{array}$ & Various types of vegetables & West Sinjai \\
\hline 4 & $\begin{array}{l}\text { Special Interest Foothills } \\
\text { Bawakaraeng }\end{array}$ & $\begin{array}{l}\text { 1. Tracking } \\
\text { 2. Outbound }\end{array}$ & West Sinjai \\
\hline 5 & Agro Tourism Orchard & Different types of fruits & Telulimpoe \\
\hline 6 & Agro Tourism Orchard & Different types of fruits & South Sinjai \\
\hline 7 & River Appareng & Rafting & South Sinjai \\
\hline 8 & Sports and Gellert Family & 1. Swimming pool & South Sinjai \\
\hline
\end{tabular}




\begin{tabular}{|c|c|c|c|}
\hline No. & Name Destinations & Attractiveness & $\begin{array}{l}\text { Location(sub- } \\
\text { district) }\end{array}$ \\
\hline & & 2. Gazebo & \\
\hline 9 & Crafts Ferns & Creative craft products fern & The entire stock \\
\hline 10 & Culinary TPI Lappa & $\begin{array}{l}\text { Various types of culinary } \\
\text { processed marine products }\end{array}$ & North Sinjai \\
\hline \multirow[t]{2}{*}{11} & Swimming Pool & Swimming pool & North Sinjai \\
\hline & Muhamad Nur Tahir & & \\
\hline 12 & $\begin{array}{ll}\text { Statue } & \text { Welcome } \\
\text { Batumimbalo } & \end{array}$ & Sculpture & North Sinjai \\
\hline 13 & Sports and Baths Tallasa & Swimming pool & South Sinjai \\
\hline \multirow[t]{4}{*}{14} & Forest Park City & 1. Gazebo & North Sinjai \\
\hline & & 2. Sculpture & \\
\hline & & 3. Fishpond & \\
\hline & & 4. City Forest & \\
\hline \multirow[t]{4}{*}{15} & National Square Park & 1. Playground & North Sinjai \\
\hline & & 2. Amphi theater & \\
\hline & & 3. Stop & \\
\hline & & 4. Culinary & \\
\hline 16 & Horse Sculpture Park & 1. Fishpond & North Sinjai \\
\hline & & 2. Stand & \\
\hline 17 & $\begin{array}{l}\text { Culinary Courses region of } \\
\text { Sinjai Bersatu }\end{array}$ & Culinary Arts & North Sinjai \\
\hline
\end{tabular}

Source: Department of Tourism and Culture of Sinjai, 2020

\section{b. Market Characteristics Travelers Sinjai}

Characteristics or tourist typologies are things that need to be analyzed by a destination to learn more in depth about the suitability of the tourism products available and owned by Sinjai district with a preference of tourists' interest so that role in planning and carrying out promotion and marketing activities of tourism, will be used as the basis for development.

In general, both foreign tourists and domestic tourists visiting tourist Sinjai district is the distribution of the main entrance to the city or another province to continue its tourism activities in Sinjai district resulting in the identification of the characteristics of the market should see the development in the region.

\section{c. Characteristics of the Local Traveler}


Local tourists who visit Sinjai largely are business travelers and destinations affairs department, both individuals and groups in the form of a community and the profession that comes from the province of South Sulawesi, for example, tourists from the island of Java, including Jakarta is a tourist market that is growing very significantly so promotion and marketing strategies are needed that better. In addition, the necessary additions and improvement of land and sea transport facilities from various commercial passenger cruise lines either public or private yacht. Based on the distribution of age groups, tourists who visit Sinjai district is dominated by tourists in the age group 26 to 50 years amounted to 64.70 percent rating, followed by the age group of 17 to 25 years amounted to 27.03 per cent, and the smallest is the traveler on the age group of less than 17 years at 8.27 percent. Based on these data, local tourists who visit Sinjai district are tourists in the age group that is very produktf, ripe (mature), selective and active travelers in the age range 17 to 50 years is a group of highly productive and active so that a market share very good and the potential for developing. Based on the work and the profession, local travelers who visit Sinjai district is largely civil servants and state-owned enterprises in the amount of 53.97 percent, followed by a group of private sector employees amounted to 37.52 percent, 6.64 percent professional groups and the smallest is the group student, the student is only equal to 1.87 percent. Motivasi and purpose of visit to the local tourist district Sinjai by showing that tourists largely come in order to carry out missions and meetings in the amount of 60.79 percent. Next up is the local tourists who intend to business and trade at 23.12 per cent. Local tourists attending the event with activities, seminars and research amounted to 12.74 percent, tourists vacation destinations by 16.9 percent, and most small motivation is visiting friends, relatives, namely by 3.35 percent.

The number of local tourists visit Sinjai district to that as much as 28.17 percent of tourists is the first to Sinjai district, and the remaining 71.83 percent has been to the Sinjai district as much as 2 to 5 times. In terms of the number of tourists per visit, visit as much as 11:36 percent of tourists visiting it alone and the remaining 89.64 percent of visits with family or friends with a number of 2 to 3 people. The magnitude of the revenue of local travelers who visit Sinjai shows that are largely tourists (73.48 per cent) is a prosperous community groups heard revenues between 5.1 to 10 million/month and only a small portion travelers who earn less than 2 million/month 
Based on the obtained information source Sinjai local tourists, local tourists largely (54.68 percent) to obtain information through friends / family, followed by the media on-line, including 23.44 percent of social media, and information from other media such as newspapers, magazines, newsletters and journals as much as 21.88 percent, and no tourists get information through a travel agency, to improve search information about Sinjai through travel agencies, more intensive efforts are needed to build a relationship with the office of profit or non-profit or company as well as travel agencies both local and international in nature so that the implementation of the activities can be more widespread and increasing distribution of information about the activities carried out tourism in the district of Sinjai. In addition the use of media as a channel of distribution (distribution channel) in promoting and marketing tourism Sinjai District is not optimal, so that local governments need conduct promotions or activities that are more widespread and intense in various electronic media and global social media

Sources costs incurred by tourists during a visit to the district of Sinjai show that as much as 32.37 percent traveled at their own expense, rating reasoning 56.17 percent over the cost of an office / company, and the remaining 11.46 per cent is financed by colleagues, family as well as relatives. Judging from the frequency of trips taken by tourists who visit Sinjai district showed that as much as 42.14 percent rating that each year traveling as much as 1 to 2 times a trip. A total of 34.67 percent of tourists do 3 to 5 times in a year, 14.06 percent of tourists who travel frequency as much as 6 to 10 times, and only 9.13 percent that traveled more than 10 times a year.

The average length of a local tourist visits in the district of Sinjai 1 day. Largely tourists (79.13 per cent) have not yet made the Sinjai district as a major destination. More travelers are making Sinjai district as the premier tourist destination of special interest culture and history, nature, and certain events that stay for 2 to 3 days. In relation to cultural tourism in less economically developed coun-103tries (often referred to as ethnic tourism), Cohen (2001) argues that104hospitality, performances, and the arts become commoditized or at 105 least oriented towards outsiders (Cole, S. 2007:3). The identification of consumer's profile of cultural tourism in Moldova, allowed concluding that the most of cultural tourism consumers in Moldova are adolescents and young people up to 30 years old, mainly women, pupils or students of orthodox religion, being in a relation (Stratan, Alexandru. 
Et.All., 2015:5). The long stay which is 4 to 5 days as much as 6.51 percent, which groups of tourists with an educational, research and conducting business activities in the districts of Sinjai. Type of accommodation used local tourists during a visit in Sinjai district showed a varied selection. Largely tourists (68.73 percent) prefer to stay at the hotel. In addition, there are 14.72 percent of respondents categorized visitors since time of the visit in Sinjai district in less than 24 hours.

The amount of local tourist spending per day during a visit to the Sinjai district varies greatly with an average of Rp.500,000. Disrtibusi largest expenditure for tourists is accommodation, then eat and drink, transport, as well as souvenirs if the trend of tourist interest in activities or enjoy the appeal of destinations when visiting somewhere else correlated with motivation and plan their activities during a visit to the district of Sinjai shows the relationship significant. In addition to the activities carried out local tourist travel, type of the most popular tourist attraction by tourists is the panorama of the beach, especially at dusk (sunset) and the panoramic scenery of mountains that stretches throughout the territory of the district of Sinjai.

Local tourist options to culinary most desirable during a visit to the Sinjai district largely showed that travelers choose traditional Indonesian food and drinks and seafood (seafood). The option is more due to the lack of restaurants and eating houses were decent (representative) and selling traditional food and beverage as well as limited creativity and restaurateur communities in developing culinary products. Traveler responses to the availability of traditional food and beverage show options limited to points of sale in addition to grilled fish culinary products. Restaurants, diners and cafes that provide traditional culinary others are less appropriate in terms of comfort and cleanliness, as well as the limited souvenirs which indicates that local tourists who visit Sinjai district is more likely to buy a souvenir in the form of crops of local such as fruit, fish and seafood others, as well as typical drinks Sinjai.

Furthermore, accessibility focuses on providing facilities and infrastructure to reach tourist destinations such as highways, access and transportation facilities to various services along with traffic signs such as places to eat, lodging, places of worship, places of souvenirs, information centers and others. Then, amenitas focuses on providing a variety of tourist facilities to support the comfort, completeness and safety of tourists while in tourist locations 
such as providing a variety of culinary delights in restaurants, restaurants, local souvenirs and accommodation, should provide more attractive alternative choices.

The central government has given a great opportunity to the regional governments in their areas of tourism development. The local government is expected to more aggressively capture the opportunities available to accommodate a variety of concepts and system development of local tourism. Participation indicators developed through a participatory precess can help agencies and organizations assess and strengthen participation and sustain it beyond the initial planning stages of development (Morrisse, Janice. 2000:1).

\section{Conclusion}

The tourism potential mapping strategy in Sinjai Regency provides clues about the many opportunities for community empowerment in the tourism industry. Mapping shows the increase and expansion of tourist areas every year. The increase in tourism destinations and the availability of adequate facilities and infrastructure provide opportunities for local people to participate in the tourism industry which contributes to the empowerment of local communities. Then the tourism potential must be supported by the government in tourism development by providing regulations that are based on the wisdom of local content. The government must collaborate actively with all elements, both civil society organizations, private and stakeholders so that tourism is sustainable with the concept of halal tourism by maintaining the balance of the natural environment. The government is expected to be able to seize various opportunities for community empowerment in the regional tourism development financing system, increase appropriate technology in environmentally friendly home industries and empower communities in synergy with stakeholders, and actively carry out promotional activities for domestic and foreign tourists. 


\section{Author's declaration}

\section{Authors' contributions and responsibilities}

Write the contribution of each author here or mark the following column.

$\sqrt{ }$ The authors made substantial contributions to the conception and design of the study.

$\sqrt{ }$ The authors took responsibility for data analysis, interpretation, and discussion of results.

$\sqrt{ }$ The authors read and approved the final manuscript.

\section{Availability of data and materials}

$\sqrt{ }$ All data are available from the authors.

\section{Competing interests}

$\sqrt{ }$ The authors declare no competing interest. 


\section{References}

[1] Andi Cudai Nur \& Haedar Akib, 2018. Mapping of Local Competence

BaseIntegrated Tourism Destination Development On the East Coast of South Sulawesi, UNM Research Center, Makassar

[2] Cole, S. (2007). Beyond Authenticity And Commodification. Annals Of Tourism Research. Vol. 34 No.4 2007

[3] Creswell, JW (2011). Research Design: Qualitative Approach, Quantitative, and Mixed. Yogyakarta: Student Library.

[4] Gunn, Clare A. (1994). Tourism Planning: BasicConcept andCases. Taylor andFrancis:Washington Dc.

[5] Gruber, James (2008), Key Priciples of Community Based Natural Resource Management: A Synthesis and Interpreatation of Identified Effective a Approaches for Managing The Commons. Antioch University New England

[6] Harry, Wisdom. 2010. Community Empowerment Strategy, Bandung: Main Humanities Press

[7] Heene, A., \& et al. (2010). Public Organizational Strategic Management. Bandung: Refika Aditama.

[8] Hidayat, M. (2011). Planning And Development Strategy Attractions (Case Study Pangandaran beach in Ciamis regency, West Java). THE) Journal, I (1), 33-44.

[9] Kurniati, E.D. (2015). Industrial Entrepreneurship. Deepublish

[10] Ismayanti. (2011). Introduction to Tourism. Jakarta: Grasindo.

[11] Pendit, S. (2006). Ilmu Pariwisata. Jakarta: PT. Pradiya Paramita

[12] Putra, M.F.P. 2017. Mixing methods: an alternative research in sports science. Proceedings of the LPTK VIII National Sports Seminar. Yogyakarta: UNY.

[13] Morrissey, Janice. (2000). "Indicators of Citizen Participation: Lessons From Learning Teams in EZ/EC Communities"Community Development Journal (Oxford Journal) Vo. 35. No.1 January 2000. 59-74

[14] Robaaniyahya, R. (2016). The Role of Social Institutions for Empowering Women and Children at the Edge of Seroja in Dealing with Vulnerable Children in the City of Solo. Sebelas Maret University: https://digilib.uns.ac.id 
Edutourism Journal of Tourism Research $\quad$ p-ISSN: 2686-4746 e-ISSN: 2721-1371

[15] Santi, Ni Made. 2017. Study of Marine Tourism Against Community Welfare in the Coastal Areas of Nusa Penida Island, Bali, Bogor: IPB

[16] Suharto, Eddie. 2005. Building a Community Empowering People, Bandung: Aditama

[17] Simanjuntak, BA, Cape, F., \& Nasution, R. (2017). Tourism History: Towards Development of Tourism in Indonesia. Jakarta: Indonesian Torch Reader.

[18] Stratan, Alexandru. Perciun, Rodica and Gribincea, Corina. (2015), Cultural Tourism Potentials In Republic of Moldova Through Cultural Comsumption Among Tourists. Vol. 188

[19] Sugiono. (2017). Research Methods Combined (Mixed Methods). Bandung: Alfabeta.

[20] Suryadana, LM, \& Octavia, V. (2015). Introduction to Tourism Marketing. Bandung: Alfabeta.

[21] Theresia, A. (2014). Community Based Development. Bandung: Alfabeta

[22] Tien, C.C. (2003). The Role of Museum Cluster in the Cultural Tourism Industry. National Taiwan University

[23] Tikson, DT, \& et al. (2013). Writing Reports Module: Strategic Management.

[24] Triton. (2007). Applied Strategic Management: Corporate and Business. Yogyakarta.

[25] Main, IGBR (2017). Tourism Marketing. Yogyakarta: Andi.

[26] Destination Development Strategy Plan and the Tourism Industry Year 2015-2019 